\title{
WAKTU DALAM PERSPEKTIF AL-QUR'AN PADA AYAT-AYAT QASAM
}

\author{
XhoinulAnam \\ Fakultas Syariah Universitas islam Negeri (UIN) Malang, \\ Jl.Gajayana 50 Malang 65144 Telp. 0341-551354, 558882 \\ Faks. 0341-572533, 0341-558882.
}

\section{Abstract}

Worldly life is diametrically opposite to the heavenly one. While this worldly life is usually related to time and space. The heavenly life is neither time nor space-related dimension. In short, human being life aspect is totally different from the one that belongs to The All-Divine Allah SWT. As such, Allah is an everlasting substance which has neither beginnings nor endings. Unlike man who experiences the day and the night, Allah never feel them. Compared to human who has past and future, Allah has never ever undergoes them. Allah is Unchangeable matter which never get bigger neither grow older.

The concept of time is central to the Holy Qur'an. That is why, Allah vows using several time-related concept like Ashr, Subh, Dhuha, Lail, Nahar. This shows that time is of great importance to human being who should spend it effectively and efficiently to accomplish his objectives. To put it in enother way, man should never waste his times doing trivial thing nor behave in a manner that endangers his life and that of others. May this research findings encourage Moslem to make use of his time virtue as ordained by Allah SWT.

Ulul Albab, Vol. 8 No. 2, 2007 
Using library review method, this research attepts to discover the meanings behind those above-mentioned terms. After investigating on the subject matter to an authoritative references, this research uncovers the following findings. Subh i.e dawn: time before sun-rise which is enlightening moment for anybody to wake up from lengthi sleep in order to prepare self to seek out Allah's bounty. Dhuha, when the sun is about to rise to shine the world which can be meant a beginning of lifelyhood so that anybody should welcome it with great joyfulness. Nahar, mid day time when the sun shines fully and the men conduct their daily activities seeking His bounties. Ashar, end of the day when people start taking rest from their daily activities. Lail. i.e night time after the sun has completely set when people relax after doing their job. It is when tranguility and peacefulness prevail human's lifelihood which are of great of magnitude for development and the growth of their spiritual and physical well-being. The alteration of day and night show His Omnipotence which requires man to contemplate it in order to make him closer to Allah SWT.

Keywords: time, qasam

\section{Pendahuluan}

Bagi masyarakat muslim, al-Qur'an adalah Firman Allah yang dibawa Jibril kepada Nabi Muhammad untuk menjadi petunjuk bagi seluruh manusia karena Muhammad sebagai penerima dan penyampai al-Qur'an diyakini sebagai nabi terakhir, tidak ada lagi nabi dan rasul sesudahnya (Ibrahim, 1983:10). Ini artinya tidak akan ada lagi kitab samawi lain yang diturunkan. Al-Qur'an berperan sebagai al-Furqan, pembeda antara yang hak dengan yang batil, maw'izhah sebagai penjelas bagi segala sesuatu sebagai nasihat dan lain-lain. Kesemuanya ini menunjukkan bahwa al-Qur'an mempunyai cakupan sangat luas, baik untuk kehidupan dunia maupun akhirat. Keluasan cakupan masalah yang dibahas di dalam al-Qur'an tidak didukung dengan metode pembahasan yang sistematis. Suatu masalah dibahas di berbagai tempat, bukan pada satu ayat atau surat. Al-Qur'an tidak menggunakan metode sebagaimana metode penyusunan buku-buku ilmiah. Di samping hal tersebut, al-Qur'an sangat jarang menyajikan suatu masalah secara rinci. Ia lebih banyak menyajikannya secara ijmal atau garis besar yaitu prinsip 
pokok-pokoknya saja dan secara parsial (juz'i secara terpisah-pisah). Keberadaan al-Qur'an yang demikian inilah antara lain yang menjadi sebab kenapa ia terus menerus menjadi obyek kajian para intelektual muslim maupun non-muslim dan diyakini orang muslim sebagai kitab suci yang tetap aktual sepanjang masa. Ridla mengatakan bahwa jika al-Qur'an diturunkan dan disusun menurut gaya bahasa buku atau disusun berbabbab akan hilanglah keistimewaannya dari kitab-kitab lainnya. .

Perlu ditegaskan bahwa al-Qur'an yang berada di tengah-tengah kita sekarang ini, sebagaimana dikatakan Shihab (1995:135), diyakini tidak berbeda sedikitpun dengan al-Qur'an yang disampaikan Nabi Muhammad 14 abad yang lalu. Berbagai macam masalah yang dibicarakan al-Qur'an, di antaranya adalah tentang waktu. Masih banyak manusia dan hamba Allah yang belum memanfaatkan waktu dengan baik, padahal al-Qur'an telah memerintahkan kepada umatnya untuk memanfaatkannya semaksimal mungkin dengan berbagai amal yang baik dan berguna (Ridlo, 1998:143144). Salah satu fenomena al-Qur'an yang berkenaan dengan waktu adalah sumpah (Qasam). Kita perlu mempertanyakan mengapa Allah banyak bersumpah dengan memakai terma waktu, seperti wa al-Dhuha, wa al-Ashri? Oleh karena itu tulisan ini akan membahas secara spesifik mengenai sumpah Allah dalam al-Qur'an berkenaan dengan waktu, dan hikmah di balik itu. Selain itu, ada beberapa alasan yang mendorong untuk mengkaji masalah waktu, antara lain:

Pertama: menyadari betapa besarnya perhatian Islam terhadap waktu, baik yang diamanatkan oleh al-Qur'an maupun sunnah (Qulub, dkk, 2004: 100). Kedua: memperhatikan sejarah orang-orang muslim generasi pertama (sebagai generasi terbaik) yang sangat memperhatikan waktu, dibanding generasi berikutnya. Ketamakan mereka dalam memanfaatkan waktu mengalahkan ketamakannya dalam hal dirham ataupun dinar. Dan besamya perhatian mereka terhadap waktu telah menghasilkan antara lain: sejumlah ilmu yang bermanfaat, amal shaleh, jihad yang baik, kemenangan yang nyata, dan sebuah peradaban yang mengakar kokoh dengan panji yang menjulung tinggi. Hal ini dapat dilihat dari sejarah para sahabat, tabi'in, 
dan generasi-generasi ilmuwan dan filosof. Ketiga: Melihat kondisi riil kaum muslimin sekarang cenderung kurang memanfaatkan waktu dengan baik.

Pada prinsipnya, dimensi waktu dan masa itu tidak berlaku pada dzat Allah swt. dia tidak mengenal adanya siang ataupun malam, masa sekarang, masa yang telah lalu, dan masa yang akan datang. Allah swt tidak berkembang, berkurang, ataupun berubah. Dia tidak mengenal anak-anak, yang kemudian beranjak dewasa, lalu menjadi tua. Dia tidak berawal dan tidak berakhir. Maka ketika al-Qur'an menyebutkan Allah swt itu sebagai dzat yang Maha pertama dan yang terakhir, bukan berarti ada permulaan dan ada akhir. Zaman atau waktu yang berlalu ini adalah ciptaan Allah, sebagaimana juga makhluk yang lainnya. Karenanya, Dia Maha ada sebelum adanya makhluk di alam jagat raya ini. Maha kekal dan Maha abadi setelah hancur leburnya seluruh makhluk pada hari akhir nanti.

Waktu yang dialami manusia di dunia berbeda dengan waktu yang dialaminya kelak di akhirat. Ini disebabkan dimensi kehidupan akhirat berbeda dengan dimensi kehidupan dunia. Waktu adalah sesuatu yang relatif, oleh karena itu Allah tidak barada di dalam waktu dan tidak pula terikat oleh waktu seperti kita. Bagi Allah tidak ada siang dan tidak ada malam, tidak ada masa lalu dan tidak ada masa kemudian. Allah tidak kadaluarsa, tidak berubah dan tidak berkembang, tidak menua dan tidak membesar dan tidak berkesudahan. Dzat yang awal dan akhir. Tetapi Keawalan dan keakhiran-Nya bukanlah temporal. Bagi Allah swt. tidak ada soal "sebelum" dan "sesudah", karena waktu dan alam semuanya adalah ciptaannya (Mahmud, 2001:15). Berbeda dengan manusia yang tidak dapat melepaskan diri dari waktu dan tempat. Mereka mengenal masa lalu, kini dan masa depan. Pengenalan manusia tentang waktu berkaitan dengan pengamalan empiris dan lingkungan. Kesadaran kita tentang waktu berhubungan dengan bulan dan matahari, baik dari segi perjalanannya (malam saat terbenam dan siang saat terbit) maupun kenyataan bahwa sehari sama dengan sekali terbit sampai terbenamnya matahari, atau sejak tengah malam hingga tengah malam berikutnya.

Ulul Albab, Vol. 8 No. 2, 2007 
Perhitungan semacam ini telah menjadi kesepakatan bersama. Namun harus digarisbawahi bahwa walaupun hal itu diperkenalkan dan diakui oleh al-Qur'an (seperti setahun setara dua belas bulan pada surat al-Taubah ayat 36), al-Qur'an juga memperkenalkan adanya relativisme waktu sebagaimana di atas.

Al-Qur'an juga berbicara tentang waktu yang ditempuh malaikat menuju hadirat-Nya. Salah satu ayat al-Qur'an menyatakan perbandingan waktu dalam sehari kadarnya sama dengan lima puluh ribu tahun bagi makhluk lain (manusia).

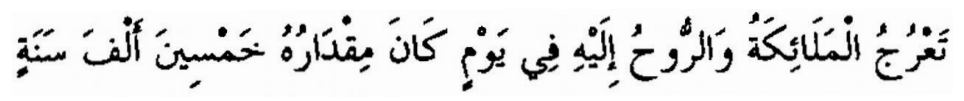

Malaikat-malaikat dan Jibril naik (menghadap) kepada Tuhan dalam sehari yang kadarnya limapuluh ribu tahun. (QS. al-Ma'arij : 4)

Ini berarti bahwa perbedaan sistem gerak yang dilakukan oleh satu pelaku mengakibatkan perbedaan waktu yang dibutuhkan untuk mencapai suatu sasaran. Batu, suara, dan cahaya masing-masing membutuhkan waktu yang berbeda untuk mencapai sasaran yang sama. Kenyataan ini pada akhirnya mengantarkan kita kepada keyakinan bahwa ada sesuatu yang tidak membutuhkan waktu demi mencapai hal yang dikehendakinya. sesuatu itu adalah Allah swt.

\section{Pengertian Sumpah}

Secara bahasa, menurut Munawwir (1997:478) sumpah adalah terjemahan dari kata qasama, hilf, dan aiman. Sedangkan secara istilah, dalam Kamus Bahasa Indonesia, ada tiga pengertiannya, yaitu: (1) pernyataan yang diucapkan secara resmi dengan bersaksi kepada Tuhan atau sesuatu yang dianggap suci untuk menguatkan kebenaran dan kesungguhannya; (2) pernyataan disertai tekad melakukan sesuatu untuk menguatkan kebenarannya atau berani menderita sesuatu kalau pernyataan itu tidak benar; (3) janji atau ikrar yang teguh akan menunaikan sesuatu

Ulul Albab, Vol. 8 No. 2, 2007 
(Departemen Pendidikan dan Kebudayaan RI, 1995:974). Sumpah adalah menguatkan salah satu dua berita dengan menyebutkan nama Allah atau sifatnya. Menurut Kazim Fathi al-Rawi, sebagaimana yang dikutib oleh Nasution (2002:6), sumpah/qasam adalah sesuatu yang dikemukakan untuk menguatkan apa yang dikehendaki oleh yang bersumpah. Hal ini ada kalanya dimaksudkan untuk menegaskan atau untuk mengingkari. Dari berbagai definisi di atas, pengertian sumpah dalam pembahasan ini lebih cenderung kapada makna sumpah adalah sesuatu yang dikemukakan untuk menguatkan berita yang ada. Dan yang dimaksud dengan sumpah Allah adalah menguatkan berita dari Allah melalui firman- Nya dengan menggunakan unsur-unsur sumpah.

\section{Terma-Terma Sumpah dalam al-Qur'an}

Adapun kata-kata yang mempunyai makna sumpah dalam al-Qur'an adalah sebagai berikut: qasam digunakan dalam al-Qur'an sebanyak 33 kali, hilf 13 kali, yamin sebanyak 71 kali dan aliyyah dua kali. (As-Salami, 1999: 21-34).

\section{Unsur-unsur Sumpah dalam al-Qur'an.}

Lahirnya suatu sumpah dikarenakan adanya unsur-unsur yang mendukungnya. Sedikitnya ada tiga unsuryang harus dipenuhi untuk sampai menjadi sebuah sumpah, yaitu : muqsam bih, muqsan 'alaih dan adat al-qasan.

\section{Macam-macam sumpah dalam al-Qur'an.}

\section{Sumpah yang dipakai oleh Allah}

Adapun ayat-ayat yang menunjukkan di dalamnya terdapat sumpah yang dipakai oleh Allah terdiri dari 38 ayat yaitu: QS. an-Nisa': 65; QS. alHijr: 72; QS. al- Hijr: 92; QS. an-Nahl: 56; QS. Nahl: 63; QS. Maryam: 68; QS. Shaffat: 1-4; QS. Shad: 1-2; QS. Zuhruf: 1-3; QS. ad-Dukhan: 1-3; QS. Qaf: 1-2; QS. ad-Dariyat: 1-8; QS. at-Thur: 1-8; QS. an-Najm: 1-3; QS. al-Waqiah: 75-78; QS. al-Hasr: 11; QS. al-Munafiqun: 1; QS. al-Qalam: 
1-2; QS. al-Haqqah: 38-43; QS. al-Ma'arij: 40-41; QS. al-Mudatsir: 32-36; QS. al-Qiyamah: 1-3; QS. al- Mursalat: 1-7; QS. an-Naziat: 1-6; QS. atTaqwir: 15-19; QS. al-Insyiqaq: 16-19; QS. al-Buruj: 1-4; QS. at- Thariq: 1-4; QS. at-Thariq: 11-14; QS. al-Fajr: 1-5; QS. al-Balad: 1-4; QS. al-Syams: 1-10; QS. al-Syams: 1-10 ; QS. ad-Dhuha: 1-3; QS. at-Tin: 1-4; QS. al'Adiyat: 1-6; QS. al-'Asr: 1-3.

\section{Sumpah yang dipakai oleh Rasulullah}

Adapun ayat-ayat yang menunjukkan di dalamnya terdapat sumpah yang dipakai oleh Rasulullah terdiri dari 4 ayat adalah: QS Yunus: 53; QS Saba': 3; QS Taghabun: 7; QS Tahrim: 1-2.

\section{Sumpah yang dipakai oleh Ibrahim}

Ayat yang menunjukkan di dalamnya terdapat sumpah yang dipakai oleh Nabi Ibrahim as. adalah: QS. Anbiya': 57.

\section{Sumpah yang dipakai oleh sebagian mukmin yang shaleh}

Ayat yang menunjukkan didalamnya terdapat sumpah yang dipakai oleh sebagian mukmin yang shaleh adalah: QS Yasiin: 16-17.

\section{Sumpah yang dipakai oleh orang-orang kafir}

Ayat yang menunjukkan di dalamnya terdapat sumpah yang pakai oleh orang-orang kafir, terdiri dari 13 ayat adalah: QS. al-An'am: 23-24, QS. al-An'am: 109, QS. al-A'raf: 49, QS. at-Taubah: 12-13, QS. Ibrahim: 44, QS. an-Nahl: 38, QS. asy-Syu'ara': 44, QS. asy-Syu'ara': 96-98, QS. anNaml: 49, QS. ar-Rum: 55, S. al-Fathir: 42, QS. al-Qaf: 34, QS. al-Qalam: 16-17.

\section{Sumpah yang dipakai oleh orang-orang munafik}

Ayat-ayat yang menunjukkan di dalamnya terdapat sumpah yang pakai oleh orang-orang munafik terdiri dari 12 ayat adalah: QS. an-Nisa': 62, 
QS. Maidah: 53, QS.Taubah: 42, 56,74, 95, 96, 107, QS. an-Nur: 53, QS. Mujadalah: 14-17, QS. Munafiqun: 1-2.

\section{Definisi Waktu}

Secara etimologi kata waktu adalah terjemahan dari al-wagtu (الوقتَ)

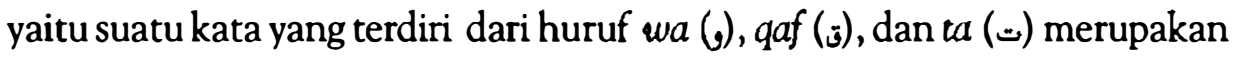
kata jadian dari akar kata وقت yang jama'nya auqât (اوقات) yang berarti time (Nuh \& Bakry, 1998:264). Sedangkan al-Waqt secara terminologi mempunyai arti :

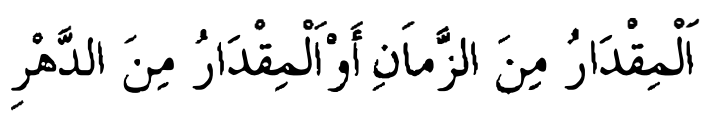

"Ukuran masa atau ukuran zaman".

Dalam Kamus Bahasa Indonesia, waktu adalah seluruh rangkaian saat ketika proses, perbuatan atau keadaan berada atau berlangsung. Dan tidak seorangpun tahu apa yang akan terjadi pada waktu yang akan datang (Depdikbud, 1995:1123). Waqt digunakan dalam arti batas akhir kesempatan atau peluang untuk menyelesaikan suatu peristiwa. Karena itu, sering kali al-Qur'an menggunakannya dalam konteks kadar tertentu dari satu masa.

Firman Allah SWT:

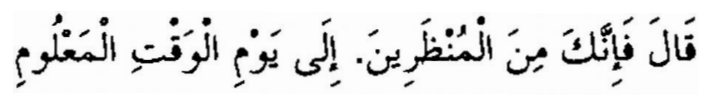

"Allah berfirman: kalau begitu maka sesungguhnya kamu termasuk orang-orang yang diberi tangguh sampai hari (suatu) waktu yang telah ditentukan". (QS. al-Hijr : 37-38).

\section{Term Waktu Dalam al-Qur'an}

Al-Qur'an memberi perhatian terhadap waktu dalam berbagai versi, dengan penggambaran yang beraneka ragam. Sebagai permulaan tentang pentingnya waktu dan besarnya nikmat Allah di dalam-Nya (al-Qardhawi, 
2001:1). Al-Qur'an menyebutkan pemberian dan karunia Allah kepada manusia :

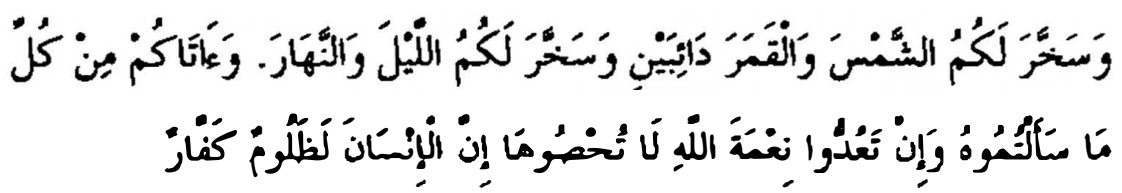

"Dan Dia telah menundukkan (pula) bagimu matahari dan bulan yang terus menerus beredar (dalam ortitnya) dan tela menundukkan bagimu siang dan malam. Dan dia telah memberikan kepadamu (keperluan) dari segala apa yang kamu mohonkan kepadaNya. Dan jika kamu menghitung-hitung nikmat Allah, tidaklah kamu dapat menghitungnya. Sesungguhnya manusia itu, sangat dhalim dan sangat mengingkari (nikmat Allah)". (QS. Ibrahim : 33-34)

Waktu adalah seluruh rangkaian saat, baik yang telah berlalu, sekarang dan yang akan datang. Dalam al-Qur'an, makna waktu tidak hanya menggunakan kata waktu saja akan tetapi menggunakan banyak term, diantaranya adalah berikut di bawah ini :

\section{Ad-Dahr}

Secara etimologi kata ad-dahr mempunyai arti: azzaman al-thawúl (الزمان ــ (الطئ ) yaitu masa yang lama. Dalam al-Qur'an kata tersebut disebutkan sebanyak dua kali (QS. al-Jastiyah :24):

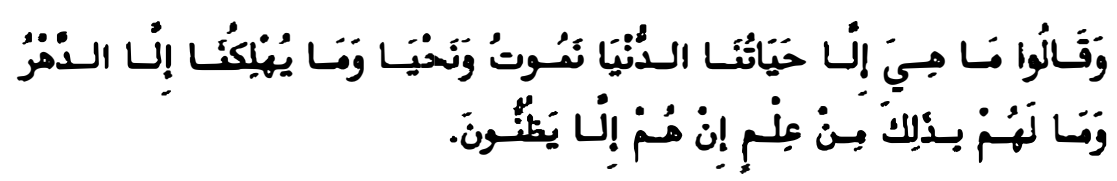

"Dan mereka berkata: Kehidupan ini tidak lain hanyalah kehidupan di dunia saja, kita mati dan kita hidup dan tidak ada yang membinasakan kita selain masa", dan mereka sekali-kali tidak mempunyai pengetahuan tentang itu, mereka tidak lain hanyalah menduga-duga saja".

Ulul Albab, Vol. 8 No. 2, 2007 
:i: . Dalam QS al-Insan:1

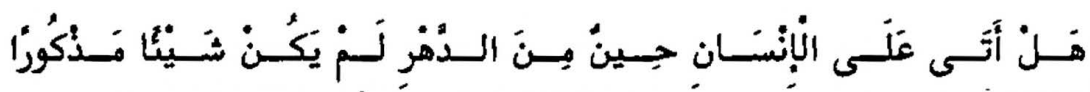

. Bukankah telah datang atas manusia satu waktu dari masa, sedang dia ketika itu belum merupakan sesuatu yang dapat disebut?

Dalam surat al-Jatsiyah, Allah mengemukakan kedurhakaan kaum musyrikin yang lain. Menurut mereka kehidupan ini tidak lain kecuali kehidupan dunia saja, tidak ada akhirat, sebagian umat manusia mati dan sebagian yang lain hidup, yakni lahir dan tidak ada yang membinasakan kitä selain perjalanan masa yang demikian panjang. Dia datang terus menerus datang secara berkesinambungan dan sebagai manusia silih berganti lahir dan mati. Kamatian bukanlah perpindahan dari satu tempat ke tempat lain. Demikian ucapan dan kepercayaan mereka. Padahal mereka menyangkut häl itu tidak mempunyai pengetahuan sedikit pun apalagi banyak. Mereka tidak lain hanyalah terus menerus menduga-duga dan mengira-ngira saja kárena melihat manusia dari saat ke saat melemah lalu meninggalkan pentas bumi ini tanpa kembali.

Kata ad-dahr (الدمى) digunakan untuk masa atau saat yang panjang dan lama yang dilalui oleh alam raya dalam kehidupan dunia ini, yakni sejak diciptakannya sampai punah atau hancurnya alam ini. Kata ini Kemudian digunakan untuk masa yang panjang dan dipinjam untuk menyebut tradisi yang langgeng sepanjang hayat, dalam arti waktu yang dilalui sejak terciptanya alam hingga punahnya. Manusia pernah suatu ketika dalam ketiadaan, walau ketika itu dahr telah wujud. Disisi lain sudah 'sểkian banyak manusia yang telah tiada, kendati masa itu masih tetap ada :(Syáfi'i, 2002:33).

Ad-dahr, sebagaimana firman Allah di atas yaitu waktu yang digunakan untuk saat berkepanjangan yang dilalui oleh alam raya dalam kehidupan ini, yaitu sejak diciptakannya sampai punahnya alam semesta. Lihat kembali QS.al-Jatsiyah ayat 4 dan al-Insan ayat 1 sebagaimana di atas. 


\section{Ajal}

Ajal yaitu masa tertentu yang ditetapkan bagi sesuatu. Dalam al-Qur'an kata ini terulang sebanyak 51 kali. Pada umumnya kata ajal digunakan untuk menjelaskan waktu berakhimya sesuatu, seperti berakhimya usia manusia atau masyarakat.

$$
\text { لكل أمة أجل }
$$

"Setiap umat mempunyai batas waktu berakhirnya usia" (QS. Yunus: 49)

Demikian juga berakhimya kontrak kerja antara Nabi Syuaib dan Nabi Musa, yang dijelaskan dalam QS. al-Qashash : 28

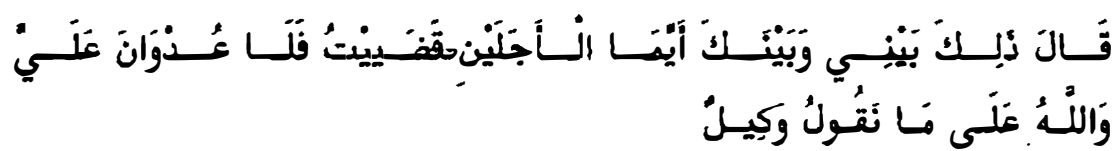

"Dia (Musa) berkata: Itulah (perjanjian) antara aku dan kamu. Mana saja dari kedua waktu yang ditentukan itu aku sempurnakan, maka tidak ada tuntutan tambahan atas diriku (lagi). Dan Allah adalah saksi atas apa yang kita ucapkan".

\section{Waqt}

Secara etimologi al-waqt mempunyai arti:

$$
\text { المقدار مـن الزمـان }
$$

"Ukuran masa / waktu untuk melakukan sesuatu".

Waqt digunakan dalam arti batas akhir kesempatan atau peluang untuk menyelesaikan suatu peristiwa. Karena itu sering kali al-Qur'an menggunakannya dalam konteks kadar tertentu dari satu masa. (QS. anNisa' : 103). 


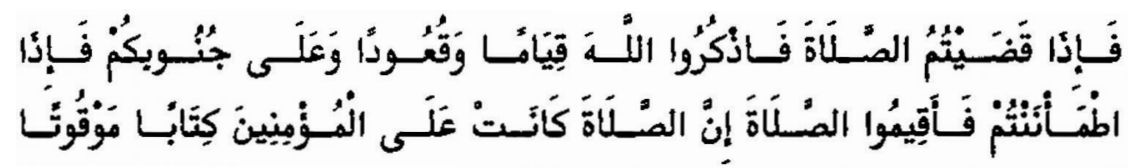

Maka apabila kamu telah menyelesaikan shalat (mu), ingatlah Allah di waktu berdiri, di waktu duduk dan di waktu berbaring. Kemudian apabila kamu telah merasa aman, maka dirikanlah shalat itu (sebagaimana biasa). Sesungguhnya shalat itu adalah kewajiban yang ditentukan waktunya atas orang-orang yang beriman.

Kata waqt terulang sebanyak 3 kali dalam al-Qur'an, 2 yaitu terdapat dalam QS Hajr : 38, QS Shad : 81 dan QS al-A'raf.

\section{Ashr}

Kata ini biasa diartikan dengan waktu menjelang terbenamnya matahari, tetapi juga dapat diartikan sebagai "masa " secara mutlak. Makna terakhir ini diambil berdasarkan asumsi bahwa 'ashr merupakan hal yang terpenting dalam kehidupan manusia. Kata "ashr sendiri bermakna "perasaan" seakan-akan masa harus digunakan oleh manusia untuk memeras pikiran dan keringatnya, dan hal ini hendaknya dilakukan kapan saja sepanjang masa.

\section{Kata yang Mempunyai Makna Bagian Waktu}

Al-Qur'an dan Sunnah sangat memperhatikan masalah waktu dari berbagai sudut dan bentuknya yang beraneka ragam. Waktu merupakan nikmat termahal di antara nikmat yang lainnya (Ghuddah, 1996:24). Karena waktu merupakan usia kehidupan dan tempat manusia berada, dan bernaung, al-Qur'an telah menegaskan betapa tinggi dan mahalnya nilai waktu di sisi manusia. Dalam QS Ibrahim ayat 32 - 34 . 


\section{Al-Lail (Malam)}

Kata النـــ / al-lailu merupakan kata yang terdiri dari huruf J / lam di awal dan akhir dan huruf ي / ya' yang merupakan kata jadian dari kata "Lailun" (ليـل) yang memiliki arti waktu setelah siang yang ditandai dengan tenggelamnya matahari (Mandzur, 1988:4115) yaitu lawan katanya siang.

Dalam "Kamus Besar Bahasa Indonesia" kata malam mempunyai arti: waktu setelah matahari terbenam hingga matahari terbit (Depdikbud, 1995:621). Dalam al-Qur'an kata lail/malam banyak diikuti dengan kata nahar/siang, yang menunjukkan bahwa dalam satu hari itu selalu berputar malam dan siang. Ada juga kata malam yang diikuti dengan kata yang lain sehingga menunjukkan waktu atau malam tertentu, seperti lailatul qadar, yaitu malam kemuliaan dirnana al-Qur'an diturunkan, barang siapa berbuat kebaikan dan beramal shaleh pahalanya akan dilipatkan seribu bulan (QS al-Qadar: 3). Lailacul mubarakah juga malam dimana al-Qur'an diturunkan (QS ad-Dukha: 3), lailatus siyam yaitu malam puasa yang dihalalkan kapada suami untuk mendatangi istrinya (al-Qur'an surat al-Baqarah:187).

\section{Kata Nahar (Siang)}

Kata nahar (النهار) yang terdiri dari kata nun (ن), ha (0), alif mad (1) dan ra () merupakan kata jadian dari akar "nahara" (نه) yang mempunyai arti cahaya di antara terbitnya fajar hingga tenggelamnya matahari (Ibnu Manzur, th:4887), atau dari munculnya matahari hingga tenggelamnya.

Menurut kamus Bahasa Indonesia, siang berarti terang dalam arti bersih, tidak ada rumputnya dan sebagainya (Depdikbud, 1995:3). Allah jadikan tanda siang itu terang, agar kamu berusaha dan mencari karunia dari Tuhanmu (QS. al-Isra':12 \& QS. ar-Rum:23) dan Allah jadikan siang adalah waktu untuk mencari penghidupan (QS. an-Naba':11). Karena itu man-faatkanlah waktu siang dengan banyak beraktifitas. Kata nahar dalam al-Qur'an diulang sebanyak 97 kali. 


\section{Kata Yaum (hari)}

Kata الهـوم / yaumu merupakan kata yang terdiri dari huruf : ي/ya', g/ wawu, dan $p / m i m$. Yang mempunyai arti hari. dalam kamus besar bahasa indonesia kata hari mempunyai 3 arti, yaitu : 1 .Waktu dari pagi sampai pagi lagi, yaitu edaran atau edaran bumi pada sumbunya. Dalam sehari ada 24 jam. 2. Waktu selama matahari menerangi tempat kita (dari matahari terbit sampai matahari terbenam). 3.Keadaan (udara alam dan sebagainya) yang terjadi dalam waktu 24 jam (Depdikbud, 1995:341). Kata yaum dalam alQur'an banyak diikuti dengan kata-kata lain sehingga menunjukkan waktu atau hari tertentu, seperti : Yaumuzzinah ("يـوم الـزين), yang secara harfiyah berarti hari hiasan atau berhias, yakni hari raya. hari raya dimaksud adalah hari dimana bendungan dan penampungan limpahan air sungai Nil dibuka, sehingga airnya mengalir keberbagai penjuru dan mengairi sawah dan ladang masyarakat luas. Hari tersebut mereka sambut dan rayakan. Melimpahnya air sungai Nil biasanya terjadi awal bulan Juli atau bulan yang bernama "Bulan Tut' dalam penaggalan Mesir kuno. Pembukaan bendungan dan penampungan itu dahulu berlangsung delapan belas hari sebelum datangnya musim gugur, atau bertepatan dengan tanggal 15 bulan September (Shihab, 2003:320).

\section{Kata Syahrun (Bulan)}

Kata syahru terdiri dari huruf $/$ syin, $\circ /$ ha', dan ,tra' yang merupakan kata jadian dari yang mempunyai arti bulan, dalam kamus Besar Bahasa Indnesia, bulan mempunyai arti: (1) Benda langit yang mengitari bumi, berinar pada malm hari karena pantlan inar matahari, (2) Masa atau jangka waktu perputaran bulan mengitari bumi dari mulai tampaknya bulan sampai hilang kembali, satu bulan sama dengan 29 hari atau 30 hari (Depdikbud, 1995:15).

Dalam al-Qur'an kata Syahrun terdapat 21 kali (Syafi'i, 1996:496). Kata syahr yang berbentuk marfu' seperti pada surat al-Baqarah ayat 185 , menjelaskan tentang adanya bulan Ramadhan yaitu bulan yang dipilih 
karena bulan yang mulia, yang di dalamnya diturunkan permulaan alQur'an sebagai petunjuk bagi manusia dan penjelasan-penjelasan mengenai petunjuk itu dan pembeda yang jelas antara yang hak dan yang bathil.

Penegasan bahwa al-Qur'an yang demikian itu sifatnya diturunkan pada bulan Ramadhan mengiyaratkan bahwa sangat dianjurkan untuk membaca dan mempelajari al-Qur'an selama bulan Ramadhan, dan yang mempelajarinya diharapkan dapat memperoleh petunjuk serta memahami dan menerapkan pemahaman-pemahamannya karena dengan membaca al-Qur'an, ketika itu yang bersangkutan menyiapkan wadah hatinya untuk menerima petunjuk Ilahi berkat makanan ruhani yang memenuhi kalbunya. Bahkan jiwanya akan sedemikian cerah, pikirannya begitu jernih, sehingga ia akan memperolah kemampuan untuk membedakan antara yang hak dan yang batil (Shihab, 2003:378).

\section{Kata Sanah (Tahun)}

Kata sanah dalam al-Qur'an terulang sebanyak 7 kali. Dan kata sinin terulang sebanyak 12 kali (Syaf'i, 1996:484). jika melihat dari segi urutan maka semuanya termasuk pada periode Madaniyah.

Sanah atau tahun adalah masa yang lamanya 12 bulan, sedangkan tahun hijriyyah adalah kalender yang dimulai perhitungannya sejak Nabi Muhammad Saw hijrah ke Madinah dari Makkah. Selain itu ada yang dinamakan tahun kabisat, yaitu tahun yang lamanya 366 hari sebab bulan Februari sampai tanggal 29, dan tahun ini terjadi 4 tahun sekali (Depdikbud, 1995:991).

\section{Tujuan Sumpah dalam al-Qur'an.}

Sumpah Allah dalam al-Qur'an pada dasarnya adalah sebuah respons terhadap suatu anggapan, tuduhan, ataupun sikap lawan bicara yang menjadi objek dakwahnya. Hal ini dapat diketahui dari beberapa contoh dalam alQur'an berikut ini: 
1. Terkadang lawan bicara mengingkari/menolak kebenaran berita. Misalnya dalam surat an-Nazi'at,79: 10-12.

2. Terkadang pada diri lawan bicara tanpak tanda-tanda keraguan terhadap berita tersebut. Misalnya dalam QS. Adh-Dhuha : 1-3

3. Terkadang lawan bicara melalaikan atau melupakan pelajaran dan hikmah yang terkandung dalam berita tersebut. Misalnya dalam QS. Al-Ashr, 103:1-3.

\section{Waktu Fajar (Sumpah Allah dalam QS. al-Fajr, 89:1-4)}

Fajr adalah nama salah satu surat dalam al-Qur'an. Surat ini disepakati turun sebelum Nabi Muhammad SAW berhijrah ke Madinah atau disebut dengan surat Makkiyah. Namanya adalah al-fajr, tanpa waw, sedikit berbeda dengan bunyi ayatnya yang pertama. Uraian utama surah ini adalah ancaman kepada kaum musyrikin Makkah, jangan sampai mengalami siksa yang telah dialami oleh para pendurhaka yang jauh lebih perkasa dari mereka, sekaligus berita gembira serta pengukuhan hati Nabi Muhammad SAW dan kaum muslimin yang pada masa turunnya ayat-ayat surat ini masih tertindas oleh kaum musyrikin Mekah (dalam Shihab, 2002:241-242).

\section{Waktu Subuh}

(Sumpah Allah dalam QS. Al-Mudatstsir, 74 : 34 dan at-Takwir, 18 : 18)

Waktu subuh dipakai oleh Allah untuk sumpah-Nya, seperti dalam QS. Al-Mudassir, 74:34 dan at-Tanwir, 18:18) yang artinya: "Sekali kali tidak ! Demi bulan dan malam ketika telah berlalu, dan subuh apabila menampakkan diri mulai terang (dalam QS.AL-Mudassir:34). Maka aku tidak bersumpah dengan bintang-bintang yang mulai menampakkan diri, yang beredar dan berlindung dan demi malam apabila telah hampir meninggalkan gelapnya dan demi subuh apabila mulai menyingsing," (Shihab, 2002:90).

Menurut Quthb (1982:2246), waktu subuh bertanda perginya waktu malam dan datangnya waktu siang, yang mempunyai pengaruh pada jiwa, 
yaitu ketika cahaya pagi baru terbit dan kegelapan mulai tersibak yang menjadikan hati menjadi khusuk dengan merenungkan dan memikirkan rahasia-rahasia alam semesta yang tak pemah berhenti, dan tidak pernah sekalipun ada ketimpangan.

Menurut Shihab (2003:603-604) kata ash-shubhu berarti sesuatu yang cerah dan bercahaya. Awal waktu siang dan pagi dinamai subuh karena kecerahan dan cahaya yang meliputinya. Hal ini mengibaratkannya dengan al-Qur'an dan petunjuk agama yang juga menyingkap kegelapan hati dan pikiran, karena dengan kehadiran tuntunan agama dalam diri manusia, maka kegelapan jiwanya pun berlalu, sebagaimana berlalunya kegelapan malam, dan kehadirannya itu adalah cahaya kebenaran yang menyinari dirinya. Menurut penulis selain tujuan di atas, waktu subuh juga di dalamnya terkandung banyak keberkahan dan keridhaan Allah.

\section{Waktu Dhuha}

\section{Sumpah Allah dalam Surat al-Dhuha.}

Surah adh-Dhuha disepakati oleh ulama sebagai surah yang turun sebelum Nabi berhijrah ke Madinah, disebut dengan surat Makkiyah (alJumali). Nama adh-Dhuha dikenal luas di kalangan ulama, hanya saja yang menamainya persis serupa dengan awal ayatnya dan ada juga yang menamainya sekadar dengan adh-dhuha.

Tema utamanaya adalah sanggahan terhadap dugaan yang menyatakan bahwa Allah telah meninggalkan Rasul Saw Akibat tidak hadimya wahyu yang selama ini telah diterima oleh Rasul Saw, sambil menghibur beliau dengan perolehan anugerah Allah hingga beliau puas (Shihab, 2003:323). Artinya, bahwa tujuan utama surah-ini adalah menguraikan apa yang disebut pada akhir surah lalu - surahal-Lail_bahwa yang paling bertakwa di antara seluruh orang bertakwa adalah dia yang mutlak paling bertakwa dalam pandangan keridhaan Allah, yakni Nabi Muhammad Saw. Keridhaan-Nya tidak terputus bagi beliau di dunia dan akhirat. Ini disebabkan karena terhiasinya beliau dengan sifat-sifat sempurna 
yang merupakan sarana mengantar kepada tujuan, bagaikan adh-dhuha yang merupakan cahaya matahari yang paling sempurna. Dengan demikian nama surah ini menunjuk kepada tujuan tersebut.

\section{Sumpah Allah dalam QS. al-Syams}

Ayat-ayat surah ay-syams disepakati turun sebelum Nabi berhijrah ke Madinah. Namanya yang dikenal dalam mushhaf surah asy-Syams. Imam Bukhari dalam kitab shahihnya menamainya surah wa asy-Syams wa adhDhuhaha, sesuai bunyi ayat pertamanya. Nama ini lebih baik dari pada sekedar menyebut surah asy-Syams karena ada surah lain yang juga menyebut kata asy-syams pada awalnya yaitu surah at-Takwir. Tidak ada nama untuknya kecuali yang disebut ini (dalam Shihab, 2003:293). Tujuan utama surah ini adalah anjuran untuk melakukan aneka kebajikan dan menghindari keburukan-keburukan. Itu ditekankan dengan aneka sumpah yang menyebut sekian macam hal, agar manusia memperhatikannya, guna mencapai tujuan tersebut, sebab kalau tidak mereka terancam mengalami bencana sebagaimana yang dialami oleh generasi terdahulu.

\section{Waktu Nahar/Siang}

Dalam al-Qur'an misalnya dinyatakan: Wan an-Nahâri idzâ jallaha (demi siang apabila menampakkannya). Kata al-nahar ditemukan 54 kali dalam al-Qur'an (Syafi'i, 1996:345). Sedangkan kalimat nahar idzâ tajalla hanya satu kali ditemukan, yaitu yang menjadi kajian ini. Untuk menyebut satu diantara kata al-nahar selain yang menjadi kajian ini adalah seperti pada surat al-Anbiya' $21: 33$ yang menjelaskan tentang Allah yang telah menciptakan malam dan siang, matahari dan_bulan. Ini menunjukkan bahwa Allah itu Maha kuasa. Sedangkan makna an-nahâr sendiri adalah waktu di mana padanya terdapat cahaya, yaitu antara terbit fajar sampai terbenam matahari. Demikian menurut syara'. Sedangkan menurut asalnya adalah waktu antara terbit matahari sampai terbenamnya. 
Menurut Quthb (2002:146-147), bersumpah dengan siang apabila menampakkannya, memberikan isyarat bahwa, yang dimaksud dengan nahar adalah waktu khusus, bukan seluruh waktu siang. "Isim dhomir" kata ganti' pada lafal jallaha jelas kembali kepada asy-Syams 'matahari" yang disebutkan dalam rangkaian ayat ini. Akan tetapi, isyarat al-Qur'an ini juga mencakup kemungkinan bahwa ini adalah dhamir bagi hamparan alam semesta. Uslub al-Qur'an ini mengandung isyarat-isyarat sampingan seperti ini yang tersimpan didalam susunan ayat, karena ia menjadi sasaran dalam manusia, yang diungkapkan secara halus. Siang menampakkan hamparan dan meyingkapnya, dan waktu siang juga memiliki bekas dan dampak bagi kehidupan manusia sebagaimana diketahui . Akan tetapi, kadang-kadang manusia lupa terhadap keindahan waktu siang dengan dampak-dampaknya itu karena seringnya berulang waktu siang, maka sentuhan sepintas dalam rangkaian ayat-ayat seperti itu dapat membangkitkan dan menggugah hati untuk merenungkan fenomena-fenomena yang sangat besar ini.

\section{Waktu Ashr (Sumpah Allah dalam QS. al-Ashr, $103: 1$ ).}

Surat ini adalah surah Makkiyah, diturunkan setelah surah al-Insyirah (al-Jamali). Urutan surat ke 13 dari segi perurutannya. Tema utamanya adalah tentang pentingnya memanfaatkan waktu dan mengisinya dengan aktifitas yang bermanfaat bagi diri sendiri dan orang lain, sebab jika tidak, maka kerugian dan kecelakaanlah yang menanti mereka.

Munasabahnya, dalam surah yang lalu Allah SWT. memperingatkan manusia yang menjadikan seluruh aktifitasnya hanya berupa perlombaan menumpuk-numpuk harta serta menghabiskan waktunya hanya untuk maksud tersebut, sehingga mereka lalai akan tujuan utama dari kehidupan ini. Dalam surah al-'Ashr ini Allah memperingatkan tentang pentingnya waktu dan bagaimana seharusnya ia diisi. Allah berfirman : wal 'Ashr, sesungguhnya semua manusia yang mukallaf di dalam wadah kerugian dan ke binasaan yang besar dan beragam (dalam Shihab,1997:173). 


\section{Waktu Malam}

\section{Sumpah Allah dalam QS. al-Lail}

Menurut Shihab (2003:310) tujuan utama surah ini adalah penjelasan tentang maksud surah yang lalu asy-syams wa dhuhahha yaitu pengendalian sempurna terhadap jiwa melalui pembuktian kuasa-Nya dengan perbedaan manusia dalam aktivitasnya, padahal tujuan mereka sama yakni meraih kelezatan syahwat perut dan seks serta apa yang menjadi dampaknya berupa kesenangan. Namanya al-Lail (malam) merupakan bukti yang sangat jelas dengan hal tersebut yakni dengan memperhatikan sumpah dan informasi yang hendak dikuatkan oleh sumpah itu. Surah ini merupakan surah yang ke-9 dari segi urutan turunnya. Ia turun sesudah surah sabbihis dan sebelum surah al-fajr, ayat-ayatnya berjumlah 21 ayat (dalam Abdurrohman, 2004:72-73).

\section{Sumpah Allah dalam QS. al-Insyiqaq}

Dalam ayat ini terdapat dua muqsam bih, yaitu

1. al-Syafaq (cahaya merah diwaktu senja). Kata as-Syafaq hanya satu kali ditemukan dalam al-Qur'an. Akan tetapi kata yangberkaitan dengannya ditemukan sepuluh kali dalam al-Qur'an yang pada umumnya bermakna takut terhadap azab Allah (Ma'luf, 1986:395). Artinya, kata syafaq atau yang berkaitan dengannya diterjemahkan dengan cahaya merah di waktu senja atau diterjemahkan dengan takut. Dalam keterangan lain dijelaskan bahwa al-syafaq jamaknya asyfaq yang bermakna al-khauf (takut) atau sisa cahaya matahari dan merahnya dipermulaan malam. al-Laily wa ma wasaq, (malam dan apa yang diselubunginya), yang berarti kumpulan kegelapan atau merupakan ibarat dari masuknya malam (dalam al-Isfahan, 1972M:560). Penjelasan kata al-lail dapat dilihat pada ayat sebelumnya.

2. al-Qamar idza ittasaqa (bulan apabila jadi purnama ). Dalam al-Qur'an kata al-qamar ditemukan 26 kali ditambah qamaran satu kali sehingga menjadi 27 kali. Kemudian dijelaskan bahwa bahasa Arab memakai 
kata al-qunar bagi planet setelah berlalu tiga malam pertama awal setiap bulan, sedangkan nama pertama sampai ketiga mereka menamainya dengan hilal. Oleh karena itu kata ittasaqa al-qamar berarti imtala'a (bulan menjadi purnama ).

3. Sumpah Allah dalam QS. al-Muddatstsir

Dalam Shihab (2003:602-603) kata (Çâā̄N) al-qamar / bulan terambil dari akar kata (qamara) yang berarti sangatputih. Seseorang yang melihat keputihan salju sehingga pendangannya menjadi remang-remang digambarkan dengan kalimat qamira ar-rajulu. Bulan dinamai qamar karena cahayanya tanpak keputih-putihan. Ada juga yang berpendapat bahwa ia terambil dari kata qamara, yang berarti menang. Seseorang yang berusaha menang tanpa usaha yang bersungguh-sungguh dinamai maqamir. Bulan dinamai qamar karena cahayanya menang atas, atau mengalahkan cahaya bintang-bintang (menurut pandangan mata telanjang).

\section{Waktu Kiamat}

\section{Dalam QS. al-Qiyamah, 75 : 1-2 )}

Dalam QS. Al-Qiyamah, 75:1-2 terdapat sumpah Allah dengan waktu Qiyamah. Menurut Quthb (1982:123), surat ini menerangkan: memenuhi jiwa manusia dengan aneka hakekat, pengaruh serta gambaran dan peristiwa, langgam dan kesan yang tidak dapat dihadapinya serta tidak pula melepaskan diri darinya. Surat ini memenuhi jiwa seseorang dengan sangat kuat dan dengan daya yang unik yang menjadikan surah ini memiliki ciri Qur'ani tersendiri, baik dalam gaya redaksinya, atau gaya musiknya.

Adapun komentar Shihab (1997) dalam ayat ini adalah: surat ini menguraikan tentang kiamat serta betapa mengerikannya peristiwa itu. Tujuan Allah bersumpah dengan hari kiamat adalah untuk menguatkan informasi yang disampaikan kitab suci ini. Di sini Allah mengisyaratkan bahwa persoalan telah menjadi demikian jelas sehingga tidak lagi diperlukan argumentasi baru. 


\section{Kesimpulan}

Allah telah memberikan banyak kelebihan terhadap waktu-waktu tertentu dengan kadar yang berbeda beda, yang harus diperhatikan oleh manusia - termasuk waktu fajar yang dipakai sumpah oleh Allah, adalah merupakan waktu yang paling tepat untuk melakukan munajat dan beribadah kepada- $\mathrm{Nya}$, karena ketenangan, keteduhan, kedamaian dan kejernihan yang meliputinya sesuai dengan kondisi jiwa manusia.

Waktu Subuh adalah waktu yang cerah, bercahaya dan dipenuhi berkah yang perlu diperhatikan untuk mempersiapkan jiwa menatap karunia Allah yang dilandasi dengan cahaya al-Qur'an sebagai petunjuk dan tuntunan dalam mencari berkah yang dihamparkan oleh Allah Swt. Oleh sebab itu Islam menyerukan Muslim untuk menyambut karuniaNya dengan bergegas bangun pagi dan mengingat Tuhannya.

Waktu Dhuha adalah waktu pencerahan, dimana sinar cahaya matahari mulai tampak setelah tertutup cahaya malam, sebagaimana cahaya wahyu yang diberikan kepada nabi Muhammad Saw. sebagai pencerahan, setelah berhenti beberapa saat. Allah menunjukkan kepada mereka kebaikan dunia dan akhirat. Pada waktu dhuha Rasul mengajarkan untuk memenuhinya dengan shalat sunnat dhuha sebagai persiapan guna menatap kebaikan dunia dan akhirat yang dipenuhi dengan rahmat Tuhan.

Waktu Siang adalah waktu dimana cahaya matahari mulai bersinar secara penuh, manusia sedang beraktivitas untuk mencari karunia Ilahi di muka bumi. Akan tetapi, manusia sering lupa terhadap keindahan waktu siang yang mensilaukan, dikarenakan kuatnya sinar cahaya siang, maka sentuhan sepintas dalam rangkaian ayat-ayat sumpah itu dapat membangkitkan dan menggugah jiwa untuk merenungkan fenomenafenomena yang sangat besar dibalik sumpah ini.

Waktu Ashr. Waktu ini bisa berarti waktu sore setelah siang atau waktu secara umum. Yang pasti Allah bersumpah dengan Ashr ini adalah guna menunjukkan akan pentingnya memanfaatkan waktu dengan sebaik mungkin dengan menjaga iman dan memperbanyak beramal shaleh. 
Waktu Malam adalah waktu dimana cahaya matahari mulai berkurang menuju ketenangan, kesunyian yang sangat dibutuhkan oleh jiwa dan raga setelah keseharian lelah karena beraktifitas. Adanya pergantian siang dan malam juga menunjukkan kekuasaan Allah dan karunia-Nya yang besar untuk selalu dipikirkan.

\section{DAFTAR PUSTAKA}

Abdurrohman. 2004. Shafwatul Bayan li Ma'anil Qur'an al-Karim (Terjemahan). Bandung: Irsyad Baitus Salam, Cet. Ke-1.

Abd. B. N. \& Bakry. O. 1998. Kamus Arab Indonesia-Inggris. Jakarta: Mutiara Sumber Widya, Cet. Kedua.

Al-Jauzyyah, Q. 1998. al-Tibyan fi Aqsam al-Qur'an. Beirut: Dar al-Fikr. As-Salami, M. 1999. al-Qasam fi al Lughah wa fi al-Qur'an. Cairo: Dar Arab al Islami, Cet.Ke-1.

Al-Syafi'i, H.al-Dalil al-Mufahras li al-Fadz al-Qur'an Karim.

Al-Jauziyah, Q. TT. At-Tibyan̈ fi Aqsamil Qur'an.

Al Qardawi, Y. 2001. Waktu dalam Kehidupan Muslim. Jakarta: Firdauscet.

Departemen Agama RI. 1979. Mushaf Al-Qur'an 30 Juz dan Tejiemahamnya. Jakarta: PT Perja.

Departemen Pendidikan dan Kebudayaan RI. 1995. Kamus Besar Bahasa Indonesia. Jakarta: Balai Pustaka.

Departeman Pendidikan Kebudayaan. 1996. Karnus Besar Bahasa Indonesia, Edisi Kedua. Jakarta: Balai Pustaka, cet.7.

Ghuddah, Abdul Fattah Abu. 1996. Qimmatuz Zaman 'Indal Ulama, Terjemahan. Jakarta: Pustaka Amani.

Hijazi, M. TT. Tafsir al-Wadhih. Bairut: Dar al-Jail.

Ibrahim, I. 1983. Al-Qur'an wa l'jazuhu al-'Ilmi. Kairo: Dar al-Fikr al-'Arabi. Ma'luf., L. 1986. Al-Munjid fi al-Lughah. Bairut: Matba'ah al-Katsulikiyah. Ma'ruf., L. 1989. Al Munjid Fi al-lughah wa Al-Islam. Bairut: Dar al-Masyriq, Cet.2.

Mandur, Ibnu. TT. Lisan al- Arab. Beirut: Dar al-Ma'arif, Jilid 5. 
Munawwir, A. 1997. al-Munawwir: Kamus Arab Indonesia. Surabaya: Penerbit Pustaka Progressif.

Nasution, H. 2002. Rahasia Sumpah Allah dalam al-Qur'an. Jakarta: Khazanah Baru.

Qutb, S. TT. Fi Dzilal al-Qur'an. Bairut: Dar al-Arabiyah li al-Tiba'ah wa al- Nasr wa al- Tauzi'.

Qutb., S. 1982. Tafsir Fi Dzilal al-Qur'an. Cairo: Daru asy-Syuruq, cet X. Insani Press, Cet. 1, Jilid 24.

Ridla., R. TT. al-Wahy al-Muhammadi (Kairo : al-Maktab al-Islâmi, th.).

Syafi'i, A. 1996. Pengantar Sholat yang Khusu'. Bandung: Rosdakarya.

Shihab., Q. dkk. 1995. Posisi Sentral al-Qur'an dalam Studi Islam, (ed)., Metodologi Penelitian Agama Sebuah Pengantar. Yogyakarta: Tiara Wacana.

Bandung: Mizan.

1995. Lentera Hati, Kisah dan Hikmah Kehidupan, 2003. Tafsir Al Misbah, Pesan Kesan dan Keserasian Al. Qur'an, Juz 'Amma. Jakarta: Lentera Hati, 1997. Tafsir Al-Qur'anul Karim, Tafsir Surat-surat Pendek Berdasarkan Unutan Turunnya Wahyu. Jalerta: Pustaka Hidayah, Cet.1. 